\title{
Educational Discussions Reflected to the Press of the National Struggle
}

\author{
Ümit Polat ${ }^{1 *}$ (1)
}

${ }^{1}$ Niğde Ömer Halisdemir University, Faculty of Education, Niğde, TURKEY

*Corresponding Author: polatumit58@hotmail.com

Citation: Polat, Ü. (2020). Educational Discussions Reflected to the Press of the National Struggle. Mediterranean Journal of Social $\varepsilon$ Behavioral Research, 4(1), 19-29. https://doi.org/10.30935/mjosbr/9597

\begin{abstract}
The articles published in the press during the period of national struggle are living documents that reflect the pain, joy, sorrow and hope aroused by the days of the national struggle. What is published and published in the press is the date of yesterday for tomorrow. The main purpose of this study was to scan Hâkimiyet-i Milliye, İrade-i Milliye, Açıksöz, İstikbal, Peyam-1 Sabah newspapers and some magazines that were published during the period of the national struggle to determine the problems of education and teachers. This study, which is a historical research, is a survey model. While fighting against the enemy during the national struggle period, education has not been neglected. Although we were at war as a nation as a whole, a congress of education was held, delegations of ilms were gathered, and ministers enacted laws on education and teachers. The numerical status of teachers in the period of national struggle, statistical values, training of teachers, legal and organizational problems were discussed by educators in the press. During the period of national struggle, teachers suffer the most from their economic problems. In this period, we see that the teachers who could not earn their salaries and could not earn a living resigned or worked in other jobs. In fact, this research is very important in terms of revealing the importance given to education even in the most critical days of the War of Independence and discussing these problems in the press.
\end{abstract} Keywords: national struggle, press, education, teacher

Received: 10 Dec. 2019 Revised: 09 Feb. 2020 Accepted: 21 Mar. 2020

\section{INTRODUCTION}

It is the name of the period between 1919 and 1922, when the Turkish nation joined forces and defended its country and eliminated the occupation. The period of national struggle is the general name of a period of struggle that began when Mustafa Kemal Ataturk set foot in Samsun on May 19, 1919. The period of national struggle is a turning point in Turkish history with its unique characteristics. In addition to reflecting the political, economic and cultural characteristics of the previous period, it also formed a structure that would form the basis of the republican period that came later. The period of national struggle has become a turning point in Turkish history with its unique features. In addition to reflecting the political, economic and cultural characteristics of the previous period, it also formed a structure that would form the basis of the later republican period.

When we look atthe socialstructure during the national period; extraordinary war conditions in terms of Anatolia have reduced social differences. During this period of national struggle, when social power began to change, they caused turmoil and disorder by ignoring turkish official rulers by making various outbursts in the minorities who have lived in this land for many years and accepted this land as their homeland. Even in towns, none of the minorities have been made unsustainable. The main reason for this is the arbitrary practices of the Ionian States occupying Istanbul and the attempted outbursts of nonMuslim people who face them (Topuzlu,1994:199-203).

Karaosmanoglu, who is one of the intellectuals of national importance, describes Istanbul as follows in his articles and novels in the newspaper:

"Istanbul, the capital of the state, almost cut off its interest in Turks after the Arm armid. The city is divided into two sections. Although it's not official, that's what it looks like. The first word you will be in every right-left shop in Istiklal street and Beyoğlu is either Greek or French. Galata region is in a position not to search for them. On the other hand, the Turkish part continues to exist in silence" (Karaosmanoglu,1981:10-12).

Halide Edip Adivar, who is also one of the authors of the period of struggle, expresses Istanbul with the following sentences: "Istanbul is like a circus square. In the dust and mud, many
clowns stomp, shout and jump, somersault from morning to
night. But Istanbul is not having fun, on the contrary, Istanbul
is entertained. Istanbul welcomes and entertains these
foreigners from all over the world. Social spite covered all 
individuals, and children had their share of it. So much so that Christian children do not pass through Turkish neighborhoods and Turkish children do not pass through Christian neighborhoods without beating each other. Moreover, there is not a single child who is not involved inthis" (Adivar, 1971:49).

The beginning of the national struggle has been the scene of so many different events that it reminds of chaos with its appearance. A country with no borders, two separate governments, multi-front warfare, on the one hand, the rapid collapse of a state, and on the other hand, the birth of a new state.

In short, intertwined, difficult to separate, long chain of events. The person of that day became a bridge to the fall of a state that ended and the establishment of a new state. Although there are political, economic and social problems in the importance of national, cultural and social activities continued despite such negative events both in Anatolia and in major cities such as Istanbul, especially educational activities continued actively. During this period, we see that discussions on education and teacher problems are reported in the press. In this context, the press of the struggle (1919-1923) has special importance in terms of its coverage of the transition period from the Ottoman Empire to Republic Turkey. The articles published in the press during the period of national struggle are live documents reflecting the pain, joy, sadness and hope aroused by the days of national struggle. Media reports are yesterday's date for tomorrow.

During the years of national struggle, the struggle in Anatolia was in difficulties and difficulties in press publication as in all areas. There were newspapers in Anatolia that were issued in technical and material impotence. The reason for this condition is linked to factors such as money, paper and understaffing. Alhowever, alhowever they did not come out consistently, they played an important role in the formation of the Kuvay-1 Milliye spirit and raising the awareness of the nation. The Anatolian press has also started to take shape with the local press, which is mainly in publications aimed at defending its regions after the invasion of Izmir. However, in the first days of the national struggle, the publishing of the Newspapers of İrade-i Milliye and then the Hakimiyet-i Milliye, With the establishment of the Anatolian agency's Matbuat and Intelligence Directorate-i Umûmiyesi, the creation of some press centers inside and outside the country, direct assistance to the press, the Anatolian press took shape the political line set by Mustafa Kemal Ataturk, and over time, the local press reached this line and the idea of full independence within the Misak-1 National borders was defended and public opinion was established by publishing in this direction (Koloğlu,1993:10).

Between 1919 and 1923, the number of periodicals published in various regions of Anatolia is close to 200. However, these publications are concentrated in certain centers. Some of these centers are; Sivas, Erzurum, Adana, Kastamonu, Konya, Kayseri, Trabzon, Amasya,

\footnotetext{
${ }^{1}$ The hakimiyet-i Milliye newspaper, the first issue of which was published on January 10, 1920, was founded in Ankara by Mustafa Kemal Ataturk on behalf of the Delegation of the Anatolian and Rumeli Defense-i Legal Society. Mustafa Kemal was a columnist for the newspaper, which was the leader and news source of the newspapers of the Period of National Struggle. Its responsible director was Recep Zühtu. Originally published as two days a week, the newspaper was published three days a week on July 18, 1920, and published daily except Saturday, starting on February 16, 1921. The following sentence under the title of the newspaper is very important; "His profession is to dominate the will of the
}

Ankara, Giresun, Bolu, Eskisehir. Refik Khalid's Aydede, which was later published in the genre of humor, was added to this group. The important newspapers published in favor of the National Struggle are New Day, Evening, Time, Forward, Ikdam, Tasvir'i Efkâr, Tanin, Güleryüz, Büyük Mecmua (Gevgili,1983:211; Öztoprak, 1981).

Mustafa Kemal Ataturk underted the importance of the press at the beginning of the War of Independence and made attempts to publish newspapers for this. The newspaper that left its mark on this period is The Hakimiyet-i Milliye newspaper. ${ }^{1}$

Among the resources to be used in the studies to be carried out on the war of independence press, it is the newspapers that attract the most attention. The Press of the National Struggle (1919-1923) has special importance in terms of its coverage of the transition period from the Ottoman Empire to Republic Turkey. This period, the press is very effective in creating public opinion, preparing the public for a new struggle for independence, determining a common attitude and determination in the face of certain problems. The press has the role of influencing and creating public opinion. It is the most important task of the newspaper to transfer current news. Education and teacher problems are among the most common topics in the press, especially during the period of national struggle (1918-1923) (Akyüz,1988:10).

Each nation has its own education system. This system is established and developed in accordance with the social, cultural, political and economic structures and characteristics of that society. As a matter of fact, those who gave their new form to the social, cultural, political and economic structure of Turkish society immediately after the establishment of the Republic of Turkey; they have not neglected to establish the education system that will keep it alive and raise new generations in accordance with this new structure. They began their efforts to establish the new education system in the pre-Republican period, during the War of Independence (Duman, 1991:19).

While the fight against the enemy was fought during the mili struggle period, the training was not neglected. Education issues, teacher salaries, strikes and closed schools have been the subject of controversy. Although we are at war as an all-out nation, a maarif congress was held, delegations were convened, and ministers issued articles of law on education and teachers. In national awakening and organization, the status of teachers on the frontline, the status of schools, associations of representatives, activities of foreign and minority schools were reported in the press. In this context, the basic works on education and teacher problems will guide our research.

The first research that investigated and wrote this period was "The Effects of Teachers in Social Change in Turkey (1839-1950)” by Akyüz (2012). In this work, teacher problems are generally classed in six titles.

people." (Coşar,1963:123). Most of the first articles were printed by Mustafa Kemal and were considered the semi-official body of the Government of the Grand National Assembly of Turkey in terms of being the spokesperson of the National Liberation Movement, and the Hakimiyet-i Milliye newspaper was published in order to create public opinion during the occupation years and to ensure the participation of the people in the National Struggle. Some of the authors who were on the writing staff during 1920 are: Agaoglu Ahmet, Huseyin Tevfik, Huseyin Ragip Mahmut Esat, Dr. Tevfik Rüştü, Yusuf Akçura, et al. Leader, 1991: 2443). 
This classiation is as follows:

1-Teacher's numerical status

2- Teacher training problem

3- Legal status of teachers

4-Teachers' economic problems

5-Teachers' organizing problems

6- Professional publications of teachers

These problems, which Akyüz classed as six articles, formed the main topics of our thesis. In the years from 1839 to 1950, the numerical, upbringing, legal, economic, organizing situations and professional publications of teachers were examined and took their place as a basic source in the scientific world in all the researches to be done and carried out by using periodicals and archives.

The research conducted by Duman (1991) called "Teacher Training (Historical Development) in Turkey" has a comprehensive research feature in terms of teacher training in secondaryeducation and the dimensions it handles. This research discussed and evaluated the historical development, teacher training policies and practices of teacher-training institutions. In the study, the pre-Republican and Republican teacher training system, policies, national education, opinions, ideas and practices of states men were examined.

Ozturk (1996) discussed teacher training with a historical perspective with his work titled "Ataturk Era Teacher Training Policies". By addressing the educational and teacher training activities that have developed since the Tanzimat era, the original Ataturk era examined teacher training policies, thoughts and practices about teacher training, and teacher training at all levels.

In Caner Arabacı's (1991) research called "Konya Teachers of the Period of National Struggle", his teachers in Konya during the National Struggle period examined their contributions to the National Struggle and their educational activities.

Göldaş (1981)'s research titled "Teachers in the War of National Liberation" consists of three topics; Teacher Organization, First Teacher Strikes and Schools in the War of Independence.

In Saruhan's "1921 Maarif Congress", saruhan(2009) was a research conducted by scanning newspapers of that period (Hakimiyet-i Milliye, Açıksöz, Ileri, Ikdam, Peyam-Sabah, Babali, Sabah, Time, Yenigün and muallimler Mecmua, Anadolu Tedrisat Mecmua). These works, in which we give examples of education and training during the period of national struggle, are the main source works.

\section{Purpose of the Research}

The main objective of the study was to answer the following questions between 1918 and 1923 by addressing "Discussions on Education and Teacher Problems" in the National Struggle Period Press (newspapers and journals);

1. Whatare the nationalm-cadele dimportance ofeducation?

2. How were the problems of the "learners" problems reflected in the press during the period of national struggle?

\section{METHOD}

Historical research method is used in this research. Researchis a desciive study in the scanning model. Scanning models are research approaches aimed at explaining a situation that exists in the past or as it still exists (Karasar,1995:77).

During the period of research and national struggle, the reflections of "education and teacher problems" on the press were tried to be tried to be distributed. In particular, the news about education and training in Hakimiyet-i Milliye newspaper, which was the official newspaper of the period of national struggle between 1918 and 1923, was compiled and interpreted by us by looking at Istikbal Newspaper, Açıksöz Newspaper, İrade-i Milliye Newspaper, Peyam-1 Sabah Newspaper and cartoon journals of that period and examining the news found in line with the research questions using the statistical analysis and document review technique.

\section{Analysis of Data Collection Techniques}

Literature review in the research; first, the sources related to the research were evaluated and the conceptual framework was established. Domestic and international theses made in this field were looked at. The sources on the subject were national library, Turkish Grand National Assembly, Turkish Historical Institution, Ankara University "Turkish Institute of History of Infusement", Karadeniz Technical University "Faik Ahmet Barutçu”, Istanbul Municipality "Ataturk and Tariq Us Library". Then, the newspapers we sampled were scanned and the data on the education and teacher problems of the period of national struggle were collected and tried to be evaluated in a historical systematic.

\section{FINDINGS AND COMMENT}

Findings obtained as a result of the analysis of the data of the research; The importance of national struggle was gathered in five topics: Maarif organization and structure, Maarif congress, Teachers economic problems, primary school problems and questionnaire with 14 questions including education and training problems.

\section{Maarif Organization and Structure}

Maarif Nezâreti was founded on March 17, 1857 in accordance with the Islahat Edict announced in 1856. By combining separate parliamentary and overseers related to education, it has emerged as an organization within the government that will govern from a single center. Sami Abdurrahman Pasha was appointed as the undersecretary of this custody, Mekâtib-i Umumiye Minister Hajrullah Efendi was appointed as undersecretary, and Rashid Efendi was appointed as the overseer letterman (Unat, 1964:2).

On the one hand, this Maarif Ministry in Istanbul continued to exist, while on the other hand, the Maarif Custody of the new State of Turkey was established on May 2, 1920, in the days following the meeting of its Parliament in Ankara on April 23, 1920. Thus, two administrative agencies emerged, one of which was the "Maarif-i Umumiye Ministry" in Istanbul and the other was the Maarif Custody in Ankara. Although the Istanbul Maarif Ministry had no more effectiveness on schools outside Istanbul, they continued to send circulars, school programs and tools to schools (Hakimiyet-i Milliye, 8 January 1923).

Both administrations wanted to attract teachers. In this struggle, teachers contributed to the establishment of the new state by standing with the Maarif Power of State. As a result, in late 1922, with the abolition of all the Auspices of the former Ottoman administration in 
Istanbul, the Maarif Power of Association became a power of law responsible for the education of the whole country (Hakimiyet-i Milliye, 8 November 1922).

In 1920s Turkey, three different administrations wanted to dominate Anatolian schools and teachers:

a) Maarif Power of Attorney of the Turkish Parliament

b) Ministry of Maarifi Umumiye of the Ottoman Empire

c) General Directorate of Education in occupied areas of the Greeks.

Istanbul Maarif Ministry did not have any activities on schools other than Istanbul; He couldn't even control the Istanbul teachers. However, he did not stop sending circulars, school programs and teaching tools. Elementary and secondary school programs were given "deeds and vital lessons" that increased production power and sent supplies to schools for a "âyani and vital" teaching. On the other hand, the General Directorate of Education appointed by the Greeks to Anatolia announced all the schools of the occupied places with the circulars they had issued to the authorities (Ergün, 1982:15).

The education system of the period of national struggle in Anatolia was tried to be managed by the two ministries until the dissolution of the Istanbul Government as in other ministries. This situation is actually a "doublepower" in Anatolia, as Sarihan (2000) said. The first of these is the Ministry of Maarif-i Umumiye belonging to the Ottoman empire, and the other is the Maarif Custody, which was established in Ankara on 4 May 1920. In the occupied territory outside this bilateral education ministry, the Greeks formed a third educational organization by connecting educational institutions to the center with an education directorate appointed by them. Thus, all the occupied schools had to work under the Greek government. In fact, three states in Anatolia and their ministries have tried to direct education depending on their thoughts. The first action taken by the Greeks isto change the content of the current history course and to make Greek officially accepted by 19 82:14-15 byingringout compulsoryGreek lessons in all schools.

Both administrations wanted to attract teachers. In this struggle, teachers contributed to the establishment of the new state by standing with the Maarif Power of State. After all, in late 1922, with the abolition of all the Auspices of the former Ottoman administration in Istanbul, the Maarif Power of Association became a power of law responsible for the education of the whole country (Hakimiyet-i Milliye, 8 November 1922).

On these developments, a comment was made in the article titled "Schools of Turkey" in Hakimiyet-i Milliye Newspaper:

The Greeks want tosettle inTurkey and dismantle the Turkish spirit that many centuries and life have attached there, and they know that they will definitely melt within theTurkish economy. Political and administrative provisions are finally powerful enough to have little share. It is the spirit of the nations that created the real power. Maarif Director Umumiyesi, who has been appointed to Turkey, collects all schools under Greek administration under an order. All points are under Greek rule in schools. The Greeks are taking the tedrisat menbags. The muallims will receive instructions from Athens, as will the Greeks. In fact, while the director continued his public declaration, "for now, we are changing the history tedrisat with only language lessons. It will be a picture of a
Greek language. After that, there is no private and official school. They will all be gathered under one administration (Hakimiyet-i Milliye, 7 November 1920).

The Greeks calculated that they were eternally themselves on Turkish soil and that their historical roots were in this geography and that this land would be taken from the invading Turks, and firstly made plans to neutralize the teacher community that organized the people in the National Struggle by linking the educational dryings to them. In the article titled "A painful specimen in the Drinking of The Muallims" in istikbal newspaper, "We Must Raise Young People as Nationals", it is very important for the Greeks to reveal what kind of policy they are following. If we look at the content of the story:

A girl about eight years old who came from Edirne a few days ago was presented to the student by Haydar Bey, one of the participants who gathered there to mark the feast. Under the suggestion of a Greek Muallim, who the Greeks assigned to the Inas School upon the occupation of Edirne, those who were there saw what this poor innocent was cheering on. This girl who said her elephant-truth father was a martyr,

He said that the Greek muallim had forced Muslim children to take a job when he attended class in the morning; Then, when asked what anthem he knew:

I know the Constantine anthem, I'll read it if you want, it taught me that, you have to stand up so I can read it. Because Konstantin was a very big man.” The girl was then asked what else this Greek Muallim wanted to teach, and she said, "The Turks are the worst nation, they taught us that in class."

No nation in the world is so raping. And no administration or invasion is so iptidai. "Here you can see that this girl who arrived a few days before Edirne is slowly forgetting her sings under thousands more. Such bad suggestions are being made to our children in the countries that are infested by the Greek State, which uses the policy of representing Turks. We, the muslims, are able to act like this, and we, the muslims, are able to teach our own students the lesson of homeland and nationality. If we want to save this nation and we need the muallims to distribute wisdom in the way of saving this nation, we must first insed it without fulfilling our duties and inderating the cubs with national emotions and homeland feelings. We must work hard to raise young people of serious nationality.”

Kamil Su (1986); in his work "Occupation Pains in Manisa and ItsRegion"; how greeks changed Turkish identity and national education policies is expressed in the following sentences;

Greeks have changed their curriculums in schools that continue their education as they would like. For example, in izmir, Manisa, Aydın centers and all schools in the districts connected to them, they abolished malûmat-1 Vataniye (Dormitory Knowledge) courses and changed the programs of history courses. Since the beginning of the 1921-1922 academic year, they have put Greek lessons in secondary schools and madrassas and primary schools and have the compulsory passing of classes from this course. This course was dealt with seriously, meticulousness was taken in the selection of teachers, and officers took classes in situations where there were no civilian teachers. Greeks are attracting attention that in their efforts to 
destroy Turkish national education, they target schools that do modern education and do not touch madrassas verymuch.

Apart from the information summarized from Kamil Su above, there are many examples showing the attitudes and behaviors of the occupiers teachers and schools in many provinces.

At the same time, the Greeks moved the tools and equipment of some schools to their home countries. This article was published in the newspaper "Peyam-1 Sabah" using the following statements

Greeks' Ingenuity

Ankara "The Greeks transported all the machinery and tools of the printing press-i province of The School industry in Izmir toAthens" (Peyam-1 Sabah Newspaper, 8 January 1922).

\section{Maarif Congress}

Mustafa Kemal has caredabout my educationas well as the national country. While addressing education in parallel with the war of liberation, he emphasized that education is important in the congresses where the war was organized and appealed to his views by attracting the attention of his close circle on this issue. Ataturk, who emphasized the awareness of the teachers, took on the task of addressing the teachers and guiding the education policy to be followed in every dormitory trip. In the days when the sound of cannons was being heard in Ankara, he organized a general education congress in Ankara as if to show that the war could not prevent the regulation of education. After that, we see that Ataturk has put education and education in the forefront and continues his efforts to organize it.

More than 250 male and female teachers, school principals and maarif principals from all over the country were gathered later in the congress, which Maarif Deputy Hamdullah Suphi convened in Ankara on July 16, 1921 and opened with 180 members (Hakimiyet-i Milliye, July 22, 1921).

According to Akyüz (1978), he wished success to the congress by telegram at the Istanbul Muallimler Society. Mustafa Kemal opened the congress with a lecture and squeezed the hands of the teachers one by one.

Hakimiyet-i Milliye Newspaper gave the following information by using the phrase "Hak Tariq, The Previous Day Maarif Congress Was Opened":

"On the occasion of the opening of the Maarif Congress, His Holiness Mustafa Kemal Pasha gave a lecture on education. Nutukta continues his speech after ingesting that our country is in ruins due to harb and that our nation is obliged to carry on its life under this evil: However, today we are obliged to isolate our mad and spiritual power against the enemy, which will be maarifle. (...) Our nation's ink is not possible with foreign culture, but with the new culture we will create. This culture should be in keeping with the choice of our nation. Let us not forget that while raising our children and young people, we are obliged to raise a generation that is capable of defending against every force that attacks our unity and our existence. It is possible to insimilar this quality and the spirit of the new generation. When raising this generation, it is neededto follow them with strong enthusiasm andvirtue" (Hakimiyet-i Milliye, 17 July 1921)
Later, M. Kemal gave his opening speech:

M. Kemal began his speech by saying, "Reverend Ladies, Masters!" Talking about the depression caused by World War I in the country, ankara being the center of the national struggle and the opening of the Turkish Parliament, he continued: “Today Ankara is the scene of the 'substitution' of the Turkish Congress of Muallimler and Muallimeler, which will establish the national maarif of national Turkey. M. Kemal stated that the procedures of collection and decency followed so far are an important factor in the history of our nation's decline. With the national training program; he said that they aimed for a culture that is in accordance with our national character and history, away from the supersti of the old era and foreign ideas that have nothing to do with the characteristics we had from birth, away from all factors coming from the east and west. M. Kemal said of the education that should also be given to children and young people: "Let us not forget that we are obliged to raise a generation that is capable of defending against every force that attacks our unity and existence while raising our children and young people." At the end of his speech, M. Kemal finishes his speech wishing that he sees the muallims as the respected pioneers of our future liberation, that his duties are very hard and vital, and that they will be victorious and successful in this way (Hakimiyet-i Milliye, 17 July 1921).

The main theme of the congress, which started with the opening speech of Mustafa Kemal Pasha, was raised on two main issues. The programs and teaching periods of the first schools are secondary education programs and durations.

In the congress, it was discussed that the People's Schools project should include the language, religion and accounting issues that the villagers need most, not advanced programs, the fact that primary education should be increased from four to five years, courses should be put into the curriculum for working life, and the villagers could not withstand five or six years of iptidai schools in terms of duration and burden, and that the people's education should include the language, religion and accounting issues that the peasants need most, not advanced programs. During the session that began on July 19, 1921, Kazim Nami, The Director of The Central Tedrisat and also a Founding Member of the Turkish Muallileri Association, made a speech and informed the Deputy Maarif Hamdullah Bey and the members (Hakimi Milliye, 20 July 1921).

At this congress, both Mustafa Kemal and then-Minister of National Education Hamdullah Suphi tried to show their importance to education. The main importance of the congress is the meeting of teachers in Ankara during a life-and-death war and the discussion of the purposes of education. In his opening speech, M. Kemal revealed the educational principles of the newly establishedstate.

\section{Teachers' Economic Problems}

In addition to the steps taken during the Ottoman period in the field of teacher training during the National Struggle period, there is no new development. Reza Nur, the first Minister of National Education of the Turkish Parliament on the need for teachers during this period, spoke in parliament on October 19, 1920, 
"According to the numbers I have today, there are 28 sultans. A few of them are occupied. The number of boarders is 340 and the number of dayrs is 2591 . The number of teachers and civil servants is 578.20 students per teacher. He's got about 50 or 60 . Our iptidai (primary school) want 40,000 teachers." (Muallimler Mecmuası, 1923; 227).

According to the information given by Deputy Maarif Vehbi Bey to the Hakimiyet-i Milliye newspaper, there are a total of 3316 teachers in Anatolia, including 2627 students and 689 muallims. In his statement, the minister ought that the same mobilization should now be carried out for education, just as the War of Independence was mobilized. The Minister also stated that he would immediately work for the rehabilitation of the Darülmuallims (Hakimiyet-i Milliye,1921; 4).

According to Akyüz (1978; 172), the economic situation of teachers is quite bad during the Years of National Struggle. The money received by a newly appointed teacher in the profession is 400-500 cents with the "harp hike". These teachers get up to 20 liras. However, due to combat conditions, teachers are not receiving their monthly pay regularly. They didn't get paid for four or five months or even more, they sold their houses for a living, they were in debt.

Teachers who did not receive their salaries during the days of the opening of the Parliament had strikes in Ankara and Tokat. That's why some of the schools were closed.

After he came to parliament, Deputy Maarif Reza Nur continued to say after saying in his statement that teachers had not been paid for severalmonths.

"They are more victimized than all the civil servants of the state. And if the others can get paid, they don't. He can never be kept with them. I've made a lot of attempts at this. That's what the Council scholar knows. In fact, to some extent, I came to a degree that we could not find a solution for those who were paid by the muvazenei, such as the deeds and the Darülmuallimats" (Muallimler Mecmuası,1922; 48).

Reza Nur's speeches in parliament show that the main problem of national education is not only a question of money during this period, but also issues such as the closure of existing teacher schools and the dismissal of some staff. In a paper published on the economic problems of teachers, it is explained that teachers are in trouble for a living and do not receive their salaries even every six months. It is explained that teachers have to sell family heirlooms and some valuables for a living.

In the article published in The Hakimiyet-i Milliye newspaper, it is mentioned that teachers move to different professions such as clerkship, policing and merchantship every day (Hakimiyet-i Milliye, 25 March 1921).

The resignation letter sent by a teacher named Mehmet Emin to Kastamonu Maarifine draws attention in terms of showing the situation of the teachers. Mehmet Emin stated that many children were sick because they could not find anything to eat or wear due to lack of money, and therefore he announced that he had lost his daughter and then his wife. However, Mehmet Emin, who could not find money in funeral expenses, was unable to bury the funerals by donating 50 percent of his salary to a merchant. Mehmet Emin continues:

"I resign from these events in a way that I prefer to be a workalyser.
On the same page of the magazine, he mentions that they unable to encourage young people to become teachers. The journal admits that young people will be wretched if they become teachers (Muallimler Mecmuası, 1923, 245).

In the Peyam-1 Sabah newspaper, the following statements were used in the article "Salaries of the Muallims":

In yesterday's copy, we wrote that the August salary of the muallims would be leveled; However, the accounting-i-private directorate will approve the June salary for the time being so as not to leave a salary for a long time, and with the savings to be made, a salary will be leveled and the entire printing press (to be finalized) of the transaction (to be finalized) will be paid by the beginning of the year (Peyam-1 Sabah Newspaper, September 3, 1920).

It states that the employees have salaries that they do not receive and that these fees will be paid gradually.

In the article titled "Our Poor Muallims" in the newspaper İade-i Milliye in Sivas, they ask the relevant authority to eliminate their victimization in order to make a living by ingring that themuallims do not receive salaries or even colleagues who do not receive wages for six months (İrade-i Milliye Newspaper, 5 January 1921).

In the letters we received, it is complained that our employees in the center still do not even receive their October salaries. It is said that there are also those who have not received a salary for six months. It is requested from the authority to finally end this regreting situation and attempt to provide for our muallims and their warnings (İrade-i Milliye Newspaper, 5 January 1919).

\section{The Greats Are Taking It! ...}

No salaries, no money, no money... Poor little officers are being kicked out of the door they're applying for like beggars. That's the way it is! You have Nebeis!.. What do they need for money? Erkân-ı kiram, Rüesa-yıâzamve .güzar-ı kâm (noble noble nobles, great rulers and those who enjoy it) is taking... What do you need beyond... Let's stop and expect some of them... How does this active branch of the government (wheel of governance) work?... "One looks at the place, the apocalypse breaks from it” (İrade-i Milliye Newspaper, 16 February 1920).

It is stated that they do not receive their salaries and that every door they steal is closed to their faces and they start to feel like beggars, but those in the upper office of the state receive their salaries on time.

"How can Istanbul iptidai muallims take care of their affairs? "The teachers said that they did not receive a salary and that they were right about this.

It is known that iptidai muallims, who received salaries from muvazene-i-private, declared a strike after they could not receive the salary of the universe and February, and therefore two-face karib ibtidai schools were forced to take holidays. There are still no good decisions in this baboon. It is of course that they are excused in this strike attempt for the preservation and politicality of their law after they did not receive the salaries of the citizens who were suffering from the work of their family 
at this time when life was becoming increasingly private

(Açıksöz Newspaper 22 March 1920).

According to Akyüz: The reason for this is that the incomes of the already few private administrations decreased due to the war.

The economic problems experienced by the scholars in the humor magazines that emerged during the period of national struggle are depicted as humorous. In particular, the living conditions of the people in Istanbul were even more difficult. In the journal "Karagoz", published in Istanbul, the following conversations are mentioned between the "muallim, children, karagoz and in a second news article" between the muallim muallimeler and karagoz ":

Children - Oh, Uncle Karagoz, we are shaking from the cold. No coal, no wood. We don't think about lessons or games!

Muallim - Oh, Karagoz Efendi brother, you see me. It's neither on top nor at the top! They've $\mathrm{n}$ raise the officers. No one's looking for us, no one's asking. It's not a classroom, it's an icehouse. Find us a cure!

Karagoz - My children, this is the new way of training. They get you used to shivering like us. Muallim Efendi, when it comes to you, squeeze your teeth a little. Summer's two months away. You can have fun comfortably (Karagoz Magazine, 20 December 1919, No:1222).

It has faced similar economic issues in the occupied provinces. In Bursa, the iptidaiye residents, who did not receive a long salary, declared a strike, and some teachers were forced into classes by the Greeks (Açıksöz Newspaper, 3 December 1920).

In the articles published in the Ikdam Newspaper on March 5th and 18th, the following information was given about thestrike:" About two hundred iptidaiye muallimi in Istanbul announced the strike on March 1,1920, on the grounds that they did not receive their February salaries. They returned to their duties as of 13 March 1920 upon the promise that their February salaries would be paid."

\section{Problems in Primary Education (Iptidai Schools)}

In the Ottoman Empire, iptidaî schools replaced the schools after Tanzimat and can be shown as the equivalent of primary school education within today's education system. Unfortunately, the situation of iptidai schools after the First World War, which did not even need to discuss its importance within the Ottoman education system, was well below what was ideal and the standards.

When the Maarif Act was established, it took over the educational problems of the Ottoman Empire and the existing education system as is. Education did not reach large masses of people. There were schools in very few villages and $90 \%$ of the people were illitere. According to the Primary School Law of 1913 in the Empire and the Administrative Law adopted in the same year, the management and expense of primary schools were left to the Special Administrations (Administration-i-II.E.) (Basgoz, 19 68:78).

Despite the debates on education policies in parliament, we see that the courses representing the contemporary education understanding of the programs of the schools were put in place, which was explained in the news supporting this idea with the statement that it published the program of "Iptida-i Schools" after a long study by Ankara in istikbal newspaper. It's like this:
Tahsil-i Iptidai

After the long negotiations of the Ankara council, four classes of the bilum Mekatib-i Iptidaiye were decided and a uniform program was organized and organized about the courses. Iptidai by the inventor of the program;

The courses that repeat the education of the first classes are: Turkish, Elifba, Account, Goods drill, Ali works, Line (lessons)

Second Year Lessons are also: Quran, Religious lessons, Turkish, Account, Goods and exercise, Ali works, Çiziki(courses), i.e. Music.

In the Third Year of the Program Council: Maide, Turkish, Account, Hendese, Geography, History, Goods exercise, Ali works and Line, lessons from Quran and religion courses have been re-taught.

In these classes, the council gave great importance to the iptidai seniors and made the Qur'an important in the form of Kerim, Religious lessons, Turkish, Hüsnü hat, Account, Hendese, Geography, History, Goods and exercise, Ali works and Line, lessons and (Malumatı Medina and Kanuniye) (Istikbal Newspaper, 4 January 1922).

In the same newspaper, how students can enroll in iptidai schools and what documents are required are published in the newspaper as follows:

Vahdettin aka Olive Grove Sample Iptidai:

1-The school has started registration and acceptance of the request and request as of August 10, 338 .

2-Registration treatment will continue until the end of August 38 , and applications that will be made after the registration is closed will not be taken into account.

Thirty-five circuits for the first grade of the 3-school circuit will be accepted to ten requests for the second grade. The presence of other classes will not be accepted as it will be more than the order.

4-Those who will apply for registration will bring with Tezkere-i Osmaniyesi the vaccine paper and the medical report from The Mubin (explainer-explainer) from the sâriye (related to infectious diseases).

5-Those who are left with the resupply test are required to give their test by applying until the evening of Sunday, the tenth day of September. Otherwise, they will be roped in their classrooms.

6-Since Tedrisat will start on the second Saturday of September, it is acktesep that the student will start to continue from that dayon (Istikbal Newspaper, 21 August 1922).

Alhowever, alhowever many articles were published in the newspapers about iptida-i Schools on how to rehabilitate these schools, the intellectuals of that period gave very comprehensive information 
about how to solve this school problem with the articles they wrote in the newspapers. They argued among themselves. In this context, we can have a safer information if we examine the news and articles in the newspapers at the point of learning about this institution that cannot reform itself behind the age what kind of function iptida-i schools had during the period of national struggle. Especially in The Hakimiyet-i Milliye newspaper, we will examine the articles "Mustafa Rahmi, Muallim Ahmet Halit", which has many researches on education. In these researches, they brought up the disruptions of the education system and explained with examples what the content of the programs should be like.

Questionnaire with 14 Questions on Education and Training Problems

On August 5, 1923, the newspaper Hakimiyet-i Milliye asked the leading recognized scholars of the educational community about the "Answer to Fourteen Questions" survey on education and teacher problems and the opinions of the citizens on how to solve the educational problems were applied.

Eleven People from the Delegation-i Ilmiye Aza, Have Affiliated Our Survey with Pek Shayan-1 Attention Mutaalat (With Their Views).

The delegation has asked the head of the ministry to respond to the fourteen suales it has organized on various maarif issues. In this survey, only eleven people participated in this survey from the number of inks from forty people. Some people will give their answers in a day or two. Others, however, are more likely to take action from the answer, citing their preoccupiedness. In these eleven answers, it will beseen that they are very careful.

Here's how we're going to get into our survey. In the face of each of us, answers from various persons will be found and these answers are written to our administrative household respectively. Today we are revealing your opinion against the two first suales.

\section{First Question: What is the biggest problem in ourmaarif?}

The answer is; Purpose, method, program and work.

Second Question: Is our maarif on the show? And since when does this situation continue, what are the reasons for what do you repent as the most important for the izale?

"Is our maarif in progress? Is it in the organization (regression)? And since when does this situation continue, what are the reasons, what do you recommend as the most important remedy for the elimination?"

The answer is; Of course he's on the show. However, this is going very slowly compared to the neighboring nations. His old sense is that the country has not seen a moment of peace and tranquility since legitimacy. The most important remedy for isolation is the provision of peace and order in the country. "Selim Sirri"

Third Question: To what degree should the most needy breeding be in our schools?

The answer is; They're all in need of rehabilitating. It's always our ideal to raise them all more.

Our Fourth Question: What should be the order and order of rehabilitation according to a narrow or large budget?

The answer is; Maarif branches are so tight to each other that they should work with the same force on every branch as I do. "Mustafa Rahmi" from the royalty and translation committee
Ou

Our Fifth Question: How much money is needed for a subsethual

Answer: Today's maarif budget is a dream in the depiction of a place and a fundamental budget of maarif. However, I say we hope that the current budget of the maarif will at least increase ten-time.

Our Sixth Question: What is your opinion of the scholars, the students, the books?

Answer: As the professional life is determined, it will be individual and there will be the opportunity to work sincerely with the student. Perhaps ninety-five percent of school books are in need of notification and rehabilitation. "Ibrahim Alaattin" of Darülmuallimin-i Aliye Muallim.

Our Seventh Question: What do you think of the promotion of themuderrisand the muallims?

Answer: I think of their well-being as a surrogate, and the suffering of the idea must be finally put to an end, for this reason:

1- The resident should save him from the worries of the tongs,

2- Their promotions, loan sharks, deeds, notifications must be tied to the laws,

3- They should easily have the especially vesaite they need to progress in their professions and thetebbus (research and examinations),

Our Eighth Question: What kind of vesait and agency should you be prepared for those who will be thrown into tetebbua (research and examination) after the replenchment of the scholar (after higher education)?

Answer: Some of them will go to Europe. There are rich libraries, museums, darülmesai (workshops). It is necessary to prepare their mumasils with us. Libraries, laboratories, museums collecting the newest works, the capital and patronage that will encourage and provide them in their taharri and thetebbu (research and examination).

"Edirne Tedrisat Manager Nafi Attf"

Our Ninth Question: Are you in support of the same principle of male and female education?

Answer: Ahmet Hilmi Bey states that he sees the idea of "Turkish women (in) being an exorcted Turkish mother by drinking from the ifrat and tefrit movements, being the ruler of a merry and mesunest, and implying tomorrow's reprievative Turkish generation".

Our Tenth Question: How do you see the position and direction of women in knowledge and wisdom?

Answer: According to Mr. Ali Haydar, women expect a bright future in the "field of wisdom"; Mustafa Rahmi Bey also determines that "ourgirls are ahead in terms of collecting from our sons" based on the experiences of having worked in both the sultanate of boys and girls, and also believes that girls will get ahead of boys in science and science education, especially in science with special abilities such as bediiyat (aesthetics).

Our Eleventh Question: What Does It Take to Have the Same Style of Instiation (Spread) All Over the Country?

Answer: Muallim and money.

Our Twelfth Question: What Procedures Do You Think For Ecnebi Language and Facility?

What does the breeding of the darulfï depend on. What are the Needs of Various Faculties?

Answer: To have ecnebi languages in schools published by the scholars whose mother language is that language. The need for night language lessons, the reward of the muallims who translated a work from the ecnebi language by learning the language, the ecnebi language 
of the courses such as history-i public and history-i national in the schools. "Mustafa Rahmi" of the Royalty and Translation Council.

Our Thirteenth Question: What Would You Think to Heat up, Support (benefit) the Public to Iptidai Education?

Answer: According to the needs of the 19th, schools should be opened and valuable scholars should be raised.

Our Fourteer Question: What Kind of Redemeasing and Motherland Does The Maarif Iror have to do to fulfill its duty?

Answer: He should consult with the contractors and give everything to his people. "Muallim Sirri"

The results of the survey conducted by The Hakimiyet-i Milliye newspaper with the people who directed the educational understanding of this period are very important in terms of reflecting the educational understanding of the period. When the answers to the fourteen questions asked in the survey are examined, the educational problems of the period of national struggle will arise; Increasing the budget allocated to the maarife both improves the quality of education and eliminates the economic difficulties of the education and increases the motivation of the teacher. While all western countries allocate large budgets, it is emphasized that we must increase this budget. National mobilization should be announced, every citizen should contribute. They stated that the muallims left their professions due to the shortage of livelihoods, that the salaries of those who were lower than him as a position were done unfairly, and as a result, they could not be found in their place and that a very important problem would occur in terms of raising future generations.

The point at which the Turkish education staff agrees on the issue of education can be indicated as follows: According to Ergun,

The most important shortcomings of Turkish education are teachers, money, general education law, educational organization, a specific education policy and the lack of principles and systems yet" (Ergün,1982;31-32)

\section{RESULT}

The period of national struggle has been a turning point in Turkish history with its unique features. In addition to reflecting the political, economic and cultural activities of the previous period, it formed a structure that would constitute a detemel to the later republican period. Tanzimat and ii. The period that began with legitimacy brought many innovations to public life. There have been changes in society's structure of opinion. The idea of empire has completely disappeared and the idea of becoming a national state has been adopted in this period.

As a result of the victory won by the national struggle, a new change has begun in Turkish history. The old state was replaced by a modern state new regime. In a short time, this newly established state has started to make reforms in the structure of the government that concerns society. You were the pioneers of these reforms, and there were teachers. Discussions in the press: Maarif Organization and Structure, Problems in Primary Education, Economic Problems of Teachers, Maarif Congress, Hakimiyet-i Milliye newspaper On August 5, 1923, the questionnaire "Answer to Our Fourteen Questions" on the subject of "Answer to Our Fourteen Questions" is an indication of how much the period attaches importance to education. Undoubtedly, the Turkish press was of great importance in the win of the war of liberation and in the gathering of Turkish public opinion around this idea at that time. In this context, education and training policies, teachers' problems and in particular the maarif congress reflect on the press as headlines from the first page, which put the press's emphasis on education. As a result, the education and teacher problems inherited from the education discussions published in the press from yesterday to today continue today. However, although the most important awareness of the period of national struggle in education is the war in the country, it is a very important event that the problems of education are discussed and solution proposals are presented and made headlines in the press.

\section{REFERENCES}

Adıvar, H. E. (1971). Türk’ün Ateşle İmtiham. İstanbul.

Akyüz, Y. (1978). Türkiye'de Öğretmenlerin Toplumsal Değișmedeki Etkileri (1839-1950). Ankara: Pegem Akademi Yayınları

Akyüz, Y. (1980). Öğretmen Örgütlenmesi (Türkiye, Fransa, İsviçre’de ve Uluslararası Düzeyde). Ankara.

Akyüz, Y. (1988). Türk Kurtuluş Savaşı ve Fransız Kamuoyu (1919-1922). Ankara.

Akyüz, Y. (2012). Türk Eğitim Tarihi (M.Ö.1000-M.S.2012). Ankara: Pegem Akademi Yayınları.

Arabacı, C. (1991). Milli Mücadele Dönemi Konya Öğretmenleri. Konya.

Basgöz, İ., \& Wilson H. (1968). Türkiye Cumhuriyetinde Eğitim ve Atatürk. Ankara: Dost.

Coșar, Ö. S. (1963). Milli Mücadele Basın. İstanbul: Gazeteciler Cemiyeti Yay.

Duman, T. (1991). Türkiye’de Orta Öğretime Öğretmen Yetiştirme (Tarih Gelişim). İstanbul: Milli Eğitim Basımevi.

Ergün, M. (1982). Atatürk Devri Türk Eğitimi. Ankara: D.T.C. Fakültesi Yayınları.

Gevgili, A. (1983). Türkiye Bastm Cumhuriyet Dönemi Türkiye Ansiklopedisi. İstanbul: İletişim Yayınları.

Göldaș, İ. (1984). Milli Kurtuluş Savașında Öğretmenler, İstanbul 1981 İstanbul İlkokul Öğretmenlerinin Grevi (1920). İstanbul.

Kamil, S. (1986). Manisa ve Yöresinde İsgal Ahalan. Ankara.

Karaosmanoğlu, Y. K. (1981). Ergenekon Mill Mücadele Yazılan. Ankara Kültür Bakanlığı Yayınları.

Karasar, N. (1995). Bilimsel Araștrma Yöntemleri, "Kavramalar, İlkeler ve Teknikler". Ankara.

Koloğlu, O. (1993). Türk Basın Kuva-yn Milliye’den Günümüze. Ankara: Kültür Bakanlığı Yayınları.

Önder, M. (1991). Milli Mücadele'nin Gazetesi Hâkimiyet-i Milliye Nasıl Çıkarıldı? Atatürk Araștrma Merkezi Dergisi, 7(20).

Öztoprak, İ. (1981). Kurtuluş Savaşı'nda Türk Basım. Ankara: Türkiye İș Bankası Yay.

Öztürk, C. (1996). Atatürk Devri Öğretmen Yetiştirme Politikası. Ankara.

Sarıhan, Z. (2009). 1921 Maarif Kongresi. Ankara: MEB Yayınları.

Topuz, H. (2003). II. Mahmut'tan Holdinglere Türk Basin Tarihi. İstanbul: Remzi Kitabevi.

Unat, F. R. (1964). Türkiye Eğitim Sisteminin Gelișmesine Tarihi Bir Bakıș. Ankara. 


\section{Periodicals}

Hakimiyet-i Milliye Gazetesi

Açksöz Gazetesi

Irade-i Milliye Gazetesi
Peyam-ı Sabah Gazetesi

İtiklal Gazetesi

Karagöz Dergisi

Muallimler Mecmuast

\section{APPENDIX 1}

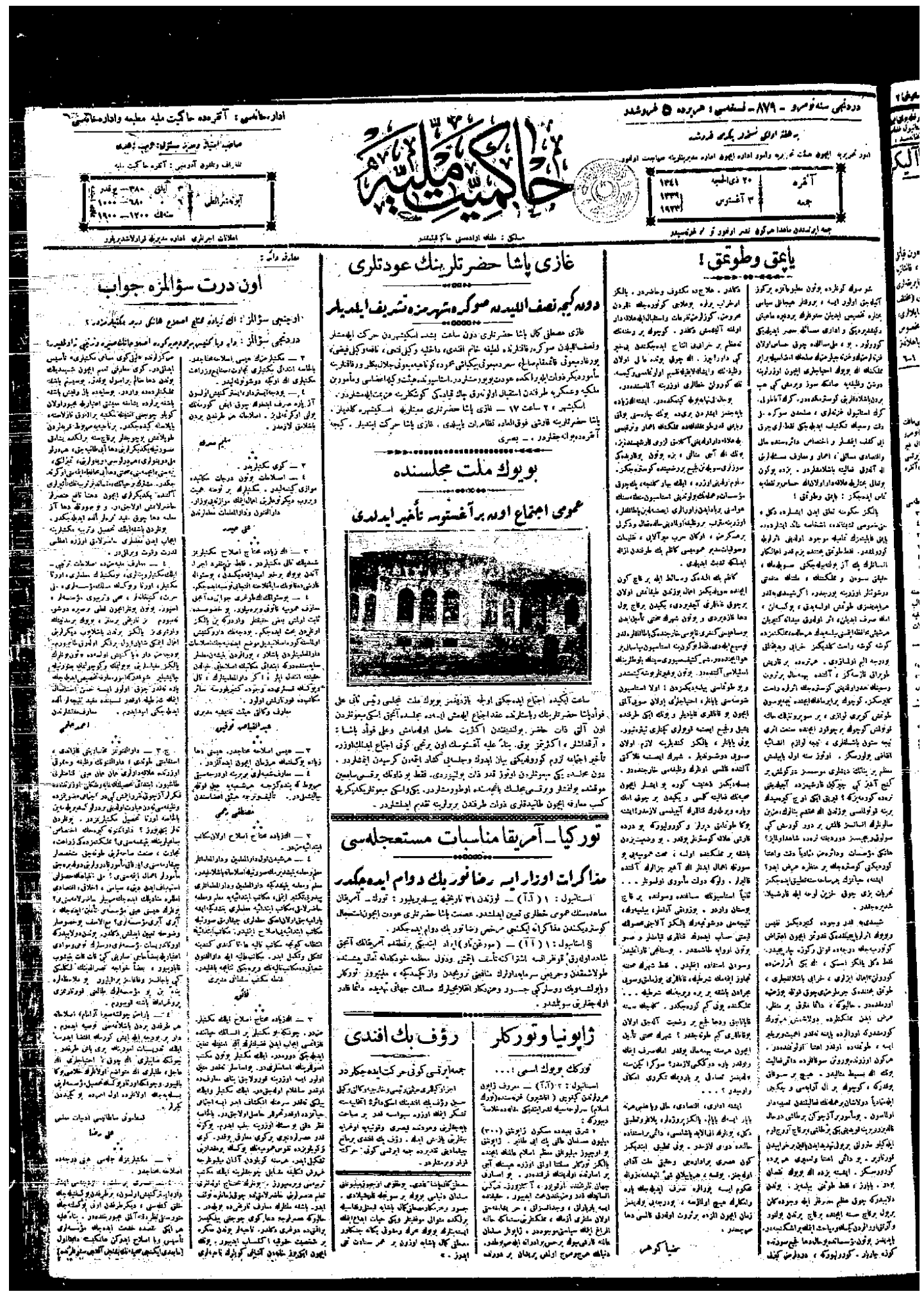

Hakimiyet-i Milliye Newspaper, 5 August 1922: Questionaire: Answers to our 14 Questions. 


\section{APPENDIX 2}

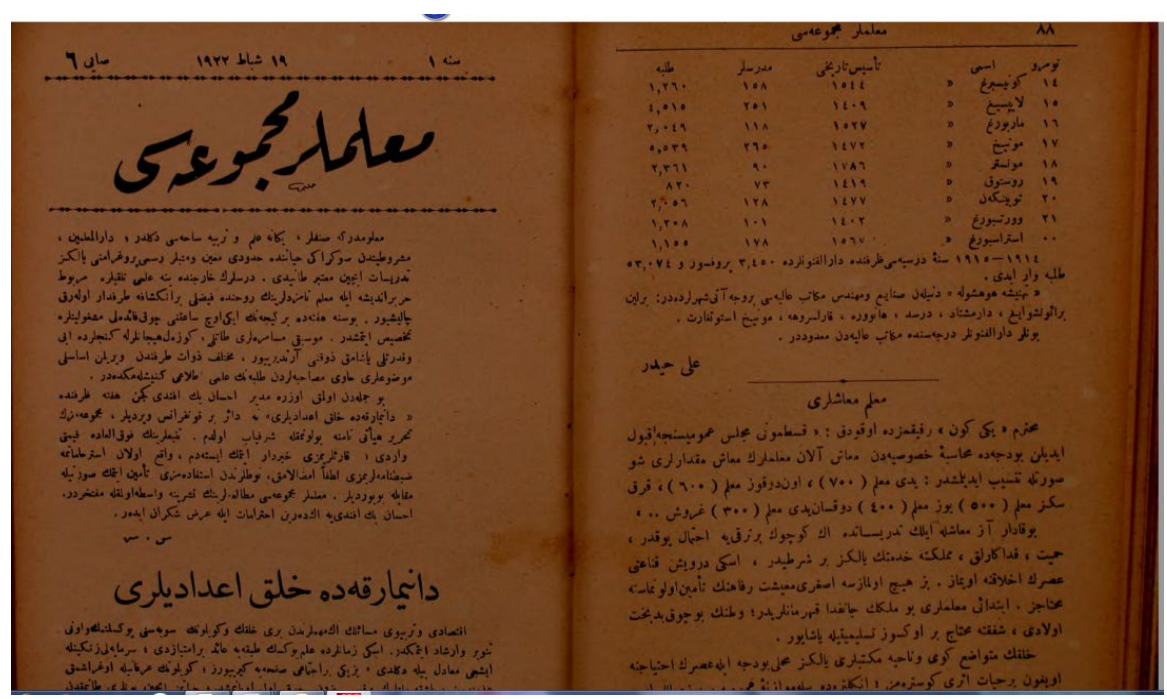

Muallimler Mecmuası, 12 December 1923: Teachers' Anthem.

\section{APPENDIX 3}

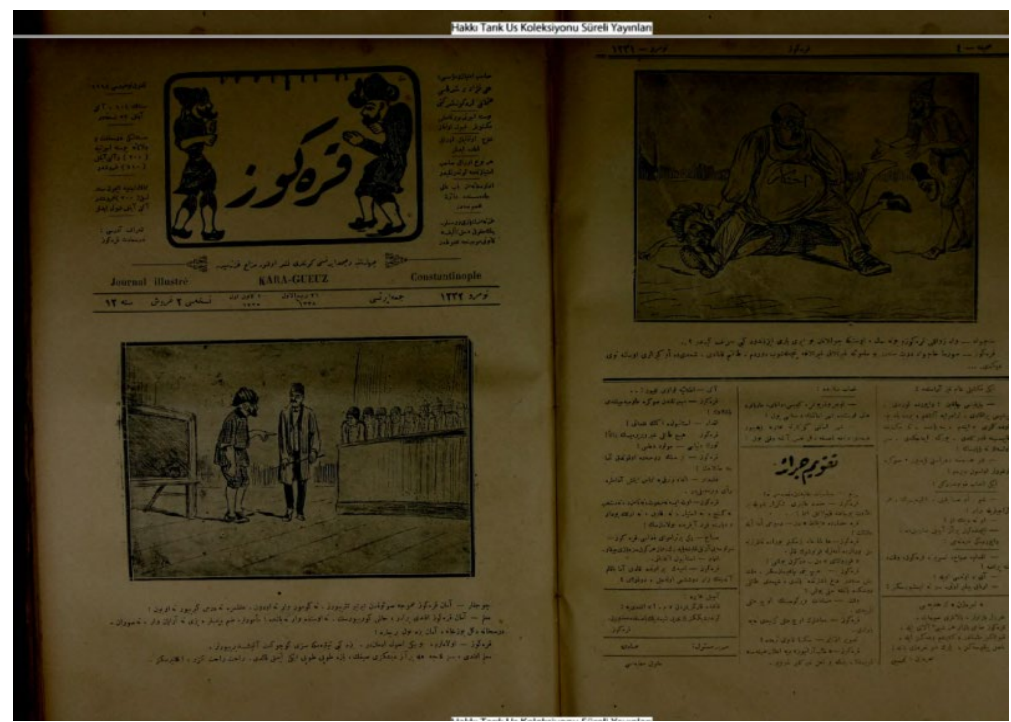

Karagöz Magazine, 20 December 1919. 